SOCIAL RESEARCH REPORTS

ISSN: 2066-6861 (print), ISSN: 2067-5941 (electronic)

\title{
INTEGRATION OF PALESTINIAN HIGH SCHOOL STUDENTS LEARNING IN AN ARAB SCHOOL IN ISRAEL
}

Sahira ABD ALRHMAN, Stefan COJOCARU

Social Research Reports, 2020, Vol. 12, Issue 2, pp. 37-47

The online version of this article can be found at:

www. researchreports.ro

\section{https://doi.org/10.33788/srr12.2.4}

Published by:

Expert Projects Publishing House

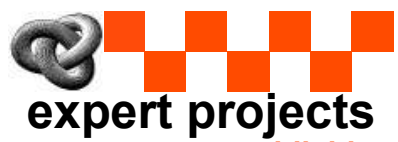

publishing

Covered by Index Copernicus International www.indexcopernicus.com

Directory of Open Access Journals www.doaj.org

On behalf of:

Center for Program and Social Development

Aditional services and information about Social Research Reports can be found at: www.researchreports.ro 


\title{
INTEGRATION OF PALESTINIAN HIGH SCHOOL STUDENTS LEARNING IN AN ARAB SCHOOL IN ISRAEL
}

\author{
Sahira ABD ALRHMAN ${ }^{1}$, Stefan COJOCARU ${ }^{2}$
}

\begin{abstract}
This paper discusses issues of identity associated with Palestinian students' integration in an Israeli-Arab high school. These students were born to Palestinian families that are considered as 'traitors' by Arabs living in the Palestinian Authority and in the State of Israel. Their parents have working relations with the State of Israel and are therefore living in a large city at the north of the country. The students experience some kind of identity conflict between them and the IsraeliArab students learning in the same school. The students who came with their parents from the Palestinian Authority, have difficulties to define themselves and they constantly try avoiding the question: Where are you from? They usually say they are from Jerusalem and they hold a blue identity card. Moreover, these students deal with language difficulties. School today constitutes an educational framework for a variety of students, characterized by different abilities and needs. This sets a rather complicated challenge to the school management and staff that have to open the school doors and provide a response to the students. This paper is grounded in theories of high school education, self-identity, conflict between identities of minorities and adolescence. It reviews the identity issues associated with the Palestinian children's national and self-identity, as well as the steps that school and the education system can take in order to promote their integration.
\end{abstract}

Keywords: identity conflict, integration of students from another culture, adolescence, Israeli-Arab culture, Palestinian Authority.

${ }^{1}$ Almutanabi High School, Haifa, ISRAEL. E-mail: sahira.abd82@gmail.com

${ }^{2}$ Department of Sociology and Social Work, Alexandru Ioan Cuza University, Iasi, ROMANIA. E-mail: contact@stefancojocaru.ro 


\section{Introduction}

Integrating Palestinian school children studying in a big city in the north of Israel: aspects of identity, and the issue of identity of high school students from the Palestinian National Authority studying at an Arab school in big city in the north of Israel. Fifteen years after the country of Israel was founded and still under martial law, the young poet Mahmoud Darwish published his famous poem "ID card". In this song he relates in a creative way to the complex question of the new identity forced on the Arabs that remained within Israeli borders. In the words of a poet he stated what is said by contemporary Palestinian politicians and scholars in Israel- we are an Indigenous minority, people of this land and not immigrants, living here by right and not by grace : roots, " Took firm hold before the birth of time". It seems that this is the determining factor in their identity until this day. Seventy years of Israeli citizenship distinctly differentiates them from the other part of their nation in other parts of the land and the world .Years of contemplation, research and writing could not untie this Gordian Knot, and the discussion into the essence and identity of this unique community continues in different fronts and in an ever changing political and generational circumstances, with internal and external disputes and without consensus. These students who come with their parents from the Palestinian National Authority have a hard time defining their identity and try at all times to avoid the question "where are you from", they are afraid or face great difficulty in sharing their origins and usually say they come from Jerusalem and have a blue id card.

\section{Literature review}

\section{The attitudes of the Israeli Arabs towards the Palestinians living in Israel}

The Israeli Arabs are those among the Arabs living in Israel that are citizens of the State of Israel. The Israeli Arabs comprise many of the country's inhabitants since the British Mandate period, who stayed in the territory of the State of Israel at the end of the War of Independence or who succeeded to return to their homes before the borders were closed. At the end of the war, this population was granted an Israeli citizenship and, within the framework of the Israeli Citizenship Law, these people became citizens of the State of Israel. This population consists also of Arab immigrants, mainly as a result of Family Reunification Procedure as well as of additional individuals who were granted the right to settle down after providing services to the State of Israel. There are those who include in this group also the Arabs who are not citizens but have been granted a 'permanent resident' status, as well as Arabs living in the territories annexed by Israel, namely East Jerusalem and the Golan Heights. Many of the Israeli Arabs identify themselves as Palestinians, citizens of Israel. The status of the Israeli Arabs who have an Israeli citizenship, differs from that of the Arab inhabitants of East Jerusalem, an area annexed to Israel in 1967 (Abo-Asba, Giusi, \& Zabar-Ben-Yehoshua, 2011). 


\section{Historical background of the Israeli-Palestinian conflict}

The state of Israel is characterized by a unique cultural-social fabric. This attribute of Israeli society was created due to the unusual combination of several factors: high social and cultural Heterogeneity of the Israeli population that immigrated from seventy different countries, life in the constant shadow of the conflict between Israel and the neighboring Arab states and the Palestinian people, the existence of a large Palestinian minority living alongside a Jewish majority that serves as the ruling class and so forth. The combination of these factures has created five central fractures in Israeli society, these affect teenagers and society as whole. The fractures are the national divide, ethnical divide, religious divide, class divide and political divide (Abo-Asba, Giusi, \& Zabar-Ben-Yehoshua, 2011).

\section{Positions and perceptions of the relationship between the Jewish majority and Arab minority}

In a research which tested the positions ad perceptions held by teenagers and intern teachers from both sectors (Abo-asba and Khidr, 2005) the researchers claim that on the one hand the dependence of Israeli Arabs on the state is instrumental and that they do not identify with Jewish symbols. On the other hand, they claim that the day to day contact with Israeli society accelerates the process of Israelization . Smooha (2008) calls this the 'modernization and politization process', integration into the Israeli society entails cultural influences specifically on Arab children and teenagers. With time socials relationships have formed between the Arab-Israeli minority and the Jewish population, this process is very much dependent on a willingness and openness for communication. This communication exists directly and indirectly by virtue of sharing a work space and being citizens of the same country.

Most Arab students attend predominantly Arab schools, schools were studying Hebrew takes an important place in the curriculum. Arab students learn the history of the Hebrew people as well as the language, the Hebrew bible, Hebrew literature and poetry all have a place in the curriculum in Arab schools. This goal emphasis the desire to act to integrate Arabs into Israeli society, to help students acquire a deep understanding of the Hebrew language, to know the Hebrew culture and its values, learn the Hebrews history and traditions, nurture Arab citizens into good civilians, emphasize the current state of integration and bring the two peoples closer together.

The relationship between the Jews and Arabs was influenced by the Balfour declaration that took place at the $29^{\text {th }}$ of November 1917 which led to an inevitable clash between the two peoples. Following this declaration, the Arabs started a struggle which aimed to prevent Britain's international commitment from coming into fruition. After the war that took place in 1948 and the establishment of the state of Israel, a state which defined itself as a Jewish state, the Arab Palestinians living in the new state became a minority. Many of them found themselves at the other side of the new country's borders and martial law was declared over the Arab population living in Israel, this state was retained until November 1966. This period had substantial ramifications over the socio-political, financial. Cultural 
and psychological state of the Arabs living under martial law and when it ended, they did not receive citizenship. The same period of time was also characterized by a strengthening of the bond between Palestinian Arabs, in the wake of the Yom Kippur war which accelerated the 'Palestinization' process in religious, economical and political terms (Ganem and otzesky-lezer, 1990).

The six-day war started in 1976. In this war the Israeli defiance forces occupied the west bank and the Gaza strip without granting the Palestinians living in these territories citizenship. In this time the Palestinians living in these territories and the rest of Israel grew closer together. Some claim that this bond was deepened after the Yom Kippur war, a war that hastened than 'palestinisation' process among the Arab population in Israel (Ganem and otzesky-lezer, 1990).

The Intifada broke out in 1987 and it was quickly defined as a national uprising of the Palestinian people. This period of time was characterized by a steep increase in ethnically motivated violent clashes, within Israel's territory the Arab citizens expressed sympathy towards their brethren on the other side of the green line, held strikes and mass protests for the Palestinian cause and called for the founding of two states for the two peoples (Ganem and otzesky-lezer, 1990; Rehes, 1992; 1993). The Oslo accord between Israel and the Palestinian Liberation Organization, the representatives of the Palestinian people was signed in 1993. A year later the peace treaty between Israel and Jordan was signed. These developments positively affected the relationship between Jews and Arabs in the middle east in general and specifically in Israel. The second Intifada, known as the Al-Aqsa Intifada broke out at the $28^{\text {th }}$ of September 2000. In the events that took place within Israeli borders in the first few days of the second intifada thirteen Israeli Arabs were killed. Following these events the Or committee was founded, this state sanctioned Commission of Inquiry was tasked with discovering the reasons behind clashes between defense forces and Israeli civilians, events that aggravated the relationship between Arabs and Jews in Israel (Ganem and otzesky-lezer, 2003).

On the eve of the foundation of the State of Israel in 1948, towards the end of the British mandate in the Land of Israel, about two thirds of the country's population were Arabs whereas one third were Jews. The United Nations resolution of 1947 called for the termination of the British Mandate and the establishment of two independent states - Arab and Jewish. The Arab leadership in the country rejected the resolution definitely. Immediately thereafter, a civil war between the Arab inhabitants and the Jewish inhabitants broke out, expanding to a total war. During the War of Independence, most of the Arabs who lived in the country left their home and became refugees, whose number was estimated at about 700,000 to 750,000 people. Some of the Arabs left their place of residence even before the war, others fled during the fights. In part of the places, Arab inhabitants were expelled by force from their houses or were asked by the Hagana organization (One of the resistance movements in the pre-State period) and the Israel Defense Force to evacuate them temporarily. Most of the Arab refugees were not allowed to return to the territory of the State of Israel after the war, and the lands and properties left behind, were transferred to the Israeli government pursuant to the Absentees Property Law. At the first stage, most of the refugees were concentrated in camps around big cities in the territories which would be called the West Bank 
and Gaza Strip. Others settled down promptly thereafter or later in neighboring Arab countries.

At the end of the war, many Arab inhabitants remained within the borders of the State of Israel. These Arabs stayed during the war in their villages or managed to return to their home before the borders were closed. According to estimates, in 1950 there were approximately 150,000 Arabs in Israel. This population and descendants thereof, as well as Arabs who were allowed to immigrate to Israel, are referred to today as Israeli Arabs. Since the Six-Day War, the Israeli Arabs have lived under the jurisdiction of several authorities. Some of them are Israeli citizens living in the territory of the State of Israel; some reside in areas in Judea and Samaria that are under the jurisdiction of the Palestinian Authority; some live in the Gaza strip under the Hamas regime; while others live in territories of neighboring countries that are included in the boundaries of the Land of Israel. Hence, the Palestinian Arab people is one people, whether they are Israeli Arabs or Palestinian Authority Arabs (Hativ, 2013; Lustig, 2003).

\section{The city of Haifa}

Haifa is the third largest city in Israel as far as the number of inhabitants is concerned and it is the home of a mixed Jewish-Arab population. The city is a member of the 15-Forum Organization, constitutes the center of greater Haifa, the main urban center of the north of Israel and is considered the capital of the District of Haifa. Haifa is a hub of transportation, industry and culture that is important and impacts all of the State of Israel as well as one of the maritime commerce centers of Israel. Already during its early days, in the $3^{\text {rd }}$ century B.C., Haifa was a port. Moreover, even in the years 2000, one of the city symbols is the port which is one of the two large commercial ports of Israel. Consequently, the Arabs wishing to live in Israel, preferred Haifa to an Arab village. Haifa is a large and mixed city, in which it is easier to be integrated into society and not be bothered by other people. Conversely, in an Arab village, all the families know each other. They consider as traitors people from the Palestinian Authority who wish to live in the State of Israel and do not allow them to live together in the village (Froind, 2008. http://www1.haifa.muni.il/mitar/chapters/chap1.pdf).

\section{Arab high schools}

\section{The education system in the Arab sector in Israel}

Since its very beginning, the Arab education system had to deal with many obstacles to which the Jewish education system was not been exposed (or exposed to a lesser degree). A significant difficulty was the village cultural identity among most of the Israeli Arabs. Within this framework, starting from a certain age, children are expected to help with the family livelihood at the expense of their studies, a perception that has been considerably prevalent. On the other hand, the urban Jewish population (sons of the new inhabitants) inculcated the European 
cultural perception, according to which excelling in school guarantees a better future. Furthermore, there was a contrast between the Jewish population, mostly the urban one, and the Israeli Arabs who mainly lived in villages which had no appropriate learning institutions (Shahin, 2009).

The War of Independence, which entailed the inclusion of the 'lion's share' of the mandatory Land of Israel under the rule of the State of Israel, exacerbated these difficulties. At the end of the war, many Arab inhabitants fled to the neighboring Arab countries while those who stayed behind had to deal with after-shocks. These included a wide-range internal immigration within the country, part of which was coerced, and emigration of many educated people among the country's Arabs to other countries. This situation, as well as the prevalent Jewish perception according to which the Israeli Arabs are 'potential enemies', led the country to assume responsibility for the education system in the Arab sector. The objective was, among others, to 'contain the threat' to the Jewish sector (Shahin, 2009).

Most curricula for the Arab sector were based on the curricula for the Jewish sector. They were translated into Arabic and delivered by teachers from the Arab sector and by Jewish teachers who had immigrated from Arab countries. The Council of Arab Education was set up in 1952 and its formal goal was to provide advice regarding the Arab cultural contents that should be included in the curricula. Nevertheless, it seemed this was merely a propaganda effect designed to emphasize the Arab involvement in the determination of the learning contents of the sector. Generally speaking, and contrary to the situation in the Jewish education, the curricula in the Arab education system aimed to neutralize the national aspect of the learning contents. Thus, the curricula mainly focused on the learning of technical details and of European culture, while considerably ignoring the cultural fundamental values related to the Arab society in general and to the Israeli Arabs in particular. In fact, the stated goal of the Arab education system under the Israeli regime was not to develop the academic skills of the Arab learners but rather to educate them for values of peace and values which were accepted by the Jewish population (Shahin, 2009).

Another most significant feature of the Arab education system in that period was the tight supervision of the learning contents and of the teaching practitioners, teachers and principals. Suspecting one of them of delivering an 'inappropriate' learning content, would result in an immediate removal from office and additional sanctions, in accordance with the martial law instructions. At the end of the 1990s, a new curriculum for the teaching of history in the Arab state high schools was written. The curriculum writers undertook to cope with the difficult challenge of integrating chapters dedicated to varied topics, such as the Arab National Movement, the Israeli-Arab conflict, and the Palestinian people in the State of Israel. The new curriculum manifested a significant progress by presenting the Palestinian narrative with regard to the events that had transpired during the years 1948-1949 and reviewing the political transformations among the Palestinians in Israel. However, it did not present an independent, consolidated and comprehensive Palestinian narrative. Thus, a large gap remained between the stated goal of the curriculum writers - promote the teaching of a unique history of the Palestinians in Israel - and the reality that was still depicted in history lessons in most of the Arab state schools. I am teaching in the "Sheizaf Al Mutanabbi" school that is 
considered as the only municipal high school in Haifa that must absorb all the students. Hence, all the students from the Palestinian Authority learn in this school. It is noteworthy that the other private high schools have refused to admit them.

Features of Israeli Arab and Palestinian Arab culture: a minority is a group of people distinguished from the majority group. We use the term 'minority' in many cases: minority of excelling students, minority of boys in a certain pathway. When we discuss the characteristics of a population in a country, the term 'minority' relates to groups that have specific features and these features have a meaning from a cultural and group viewpoint (Volkov, 2000).

Minority is a group of people within the majority population, distinguished from the majority by national, ethnic, religious, cultural, linguistic and others characteristics. All or part of these characteristics are elements that are partly attributes and partly acquired. The distinction between the types of minorities in the country has two criteria. One is an external criterion - determined by the majority group that differentiates between them and the minority group (Volkov, 2000 ). The other is an internal criterion, namely members of the minority group distinguish themselves from the majority by several aspects that reinforce the sense of belonging, identity with and solidarity between them. The differences between the majority and minority groups are manifested, among others, by cultural features, linguistic differences, customs and traditions, norms, values and external characteristics, such as clothing. In the State of Israel, in addition to the national-ethnic minorities, there are also cultural minorities.

\section{Self-identity}

Identity is an entirety of components by means of which people define themselves. These components are divided into two types: components of identity which belong to individuals since birth, such as: sex, ethic group and skin color. These are components of attributes that cannot be changed. The second type includes acquired components that can be changed, e.g. profession, religion and citizenship. Every individual chooses to highlight other components of his or her identity. Some people underscore in their identity only one component, for example the professional component: a Jordanian doctor who presents himself only as a doctor. Others highlight in their identity different components, for example the national component in addition to the religious component: a Bosnian Muslim or an American Jew who underscores in his identity the national component or the Jewish religion, together with the American citizenship. These examples illustrate the fact that people themselves define their identity by choosing those components that are important to them. Hence, we learn that the definition of identity is subjective (Ministry of Education,

Erikson (1968) defined self-identity as an inner feeling of individuals - knowing themselves, their way and future goals. This basic feeling consists of a personality nucleus (of properties, desires, wishes, talents) that does not change. This nucleus constitutes the experiential continuum of individuals, beyond situations and times. Erikson formulated his definition of identity in the following way:

This is a collection of identities that are organized by the developing personality on the one hand and that organize and direct it on the other. The integration that 
transpires in the form of self-identity is more than the sum of all its parts. This is the accumulated experience of the ability of the 'self' to merge the entirety of identifications with the specializations that have developed from the innate talents and with the opportunities offered by the social functions. The sense of selfidentity is individuals' confidence that the inner similarity and continuity match the similarity and continuity of what the individual means to others (Erikson, 1968, p. 216).

This theoretical definition relates to self-identity both as an objective standalone entity and as the individuals' internal feeling about knowing themselves, their way and their goals. Moreover, the definition relates to the way of acquiring identity as an internal process as well as an interrelation with society. As opposed to the achievement of self-identity, the identity crisis experienced by the youths can lead to the decomposition of the identity. This is a sense of insecurity regarding the goals of the youths and of the inability to define themselves - who they are and what is the direction of their life (Erikson, 1968).

According to Erikson (1968), identity implies that individuals can assess their strengths and weaknesses and decide how they want to deal with them. They have to answer to themselves where they come from and what they want to be. Moreover, Erikson maintains that identity is not a collection of individuals' beliefs about themselves. It is more than the sum of these beliefs: it is a perception that is organized in an integrative manner namely, identity is not a description of oneself, but an attempt to explain oneself. This is a task that requires a complex integration (Erikson, 1968). Finally, Identity can be defined as some sort of an 'eye' through which we are looking at the world.

\section{National identity}

National identity is a component of identity that determines the affinity and sense of belonging of individuals to their people from the cultural-ethnic aspect. This is based on a common ethnic origin, common territory, shared tradition, culture and language, common symbols and values as well as the sense of connection, identification and mutual responsibility between the individuals. The citizens of a state usually have a national identity (in the cultural-ethnic sense) that is not shared by all the citizens of this country. This identity unites all the members of that same ethnic group living in the country, distinguishing them from members of other national groups (Israeli Democracy Institute, 2008).

In Israel, there are three main national identities: Jewish identity, Arab identity and Palestinian identity. Jewish national identity - is shared by the national majority group among the citizens of Israel. It emphasizes the tradition, history and culture of the Jewish people, together with a strong sense of solidarity towards the entire Jewish people both in Israel and abroad. Some Jews have a strong national affinity and they want to maintain a contact with the world Jewry whereas others feel less affinity to the Jewish-national identity and more to their Israeli-civil identity. As opposed to the large majority that feels a considerable affinity to the Jewish people, there are few who prefer an Israeli identity to a cultural-ethnic national identity. For example, the post-Zionists who dispute the relevance of the national component in their identity (Jews who believe that Zionism has fulfilled 
its ideological mission with the creation of the modern State of Israel in 1948, and that Zionist ideology should therefore be considered at an end). They believe that the Jewish nationalism has completed its historical role and has even lost its legitimacy because of acts of injustice it has committed against Arabs and Sephardi Jews. Moreover, the post-Zionists do not attribute real importance to contacts with the world Jewry. They believe that a new people have been created in the country: The Israeli people. There are citizens who identify themselves as anti-Zionist Jews, like Neturei Karta (Guardians of the City in Aramaic, Jews who oppose secular Zionism and call for a dismantling of the State of Israel, in the belief that Jews are forbidden to have their own state until the coming of the Jewish Messiah.) that highlight their national-religious identity and oppose the existence of the country as a nation state.

Arab national identity - underscores an affinity to the Arab nations (Pan-Arab) in the Middle East. It is shared by Arab citizens and by a small number of Druze citizens who consider themselves as part of the Arab nation with which they have a common history and a common language, Arabic. Palestinian national identity - highlights an affinity to Palestine as a historical and cultural homeland. It is manifested by the cultivation of the Palestinian-Arab culture and tradition and the establishment of relations with members of their people who live outside the country (Israeli Democracy Institute, 2008). Within the context of the prolonged Israeli-Palestinian conflict, students from the Palestinian national authority often fall between the cracks. They experience a strong sense of conflict as circumstance has them living in an environment that sees them as strangers and a minority within the Israeli Arab minority group. This atmosphere makes it harder for them to socialize and connect to their fellow students and so the school takes steps to integrate them within high school life (Avivi, 2007).

\section{Conclusion}

Students who arrived with their parents from the Palestinian national authority have a hard time defining their identity and for the most part try to avoid the question "where are you from?", they fear or struggle explaining this difficult situation and often prefer to say they are from Jerusalem and hold a blue ID card, meaning they are citizens. By using the students' last name, the teacher usually knows the students origins but as a teacher must except any student and try to integrate him with his classmates. These students often have difficulties speaking Hebrew and so the school provides private tutelage to help them pass their Matriculation exams. They must also strive to integrate students in social events held in the schools so that the children feel a greater sense of belonging and acceptance within the school. It is also very important to prepare the Israeli students so that they may help accommodate their new classmates and make them feel like an integral part of the school. 


\section{References}

Abu-Asba, H., Giusi, W., Zabar-Ben-Yehoshua, N., (2011). The identity of Palestinian youth who are citizens of Israel, the degree of their identification with the state and with Jewish culture and implications for the education system. Dapim, Vol. 52. (Hebrew).

Avivi, S. (2007). Copper tray - The Israeli policy towards the Druze ethnic group 19481967. Jerusalem: Yad Ben-Zvi Publications. [Hebrew]

Bryman, A., (2012). Social research methods (4th ed.). Oxford, UK: Oxford University Press.

Creswell, J.W. (2014). Research Design: Qualitative, Quantitative, and Mixed Methods Approaches. Thousand Oaks, CA: Sage.

Erikson, E. H. (1968). Identity, youth and crisis. New York, NY: W. W. Norton Company.

Froind, I., (2008). http://www1.haifa.muni.il/mitar/chapters/chap1.pdf

Hadad, E., \& Stern, Z. (2010). Minorities in a Jewish state: Halachic aspects. Jerusalem: Israel Democracy Institute. [Hebrew]

Hativ, A. (2013). Conceptualization and measurement of identity perception and conflict perception in the context of the Israeli-Palestinian conflict. MA dissertation. Haifa: University of Haifa, School of Political Sciences. [Hebrew]

Israel Democracy Institute (2008). Parliament, 58. [Hebrew]

Lev-Ari, R. (2014). The leaders in democratic pathways. Tel Aviv: Israeli Educational Television. [Hebrew]

Lustig, I. (2003). The effect of learning of a foreign conflict on changes in the perception of the Israeli-Palestinian conflict. MA dissertation. Haifa: University of Haifa, Department of Education, Hamul Publishing. [Hebrew]

Modrik Even-Chen, H. (2000). Affirmative action in Israel: Policy definition and legislation recommendations. Jerusalem: Israel Democracy Institute. [Hebrew]

Pinchover, S. (2014). Issues in mixed methods research. Jerusalem: Hebrew University of Jerusalem. [Hebrew]

Rodnizky, A. (2015). The Arab minority in Israel and the discourse about a 'Jewish State'. Jerusalem: Israel Democracy Institute. [Hebrew]

Sabar Ben-Yehoshua, N. (2001). Genres and Traditions in Qualitative Research. Lod: Dvir. [Hebrew]

Samoha, H., (2008). Arab-Jewish Relations Index in Israel 2007. University of Haifa, The Jewish Center. (Arabic).

Shahin, R. H. (2009). Voices, mission and moral in narratives of teachers in the Arab sector in Israel. MA dissertation. Haifa: University of Haifa, School of Education, Hamul Publishing. [Hebrew]

Shkedi, A. (2011). The Meaning behind the Words, Methodologies of Qualitative Research: Theory and Practice. Tel Aviv: Ramot. [Hebrew]

Speck-Lisk, R. (2018). When and how have the Arabs and the Muslims immigrated to the Land of Israel. From the Arab conquest until the First World War (640-1914). Rishon Le-Zion: Yediot Spharim. [Hebrew]

Standel, U. (1992). The Christian ethnic groups. Israeli Arabs-Between the hammer and the anvil. Jerusalem: Academon. [Hebrew] 
Volkov, V., (2000). The Political Economy Protection Rackets in the Past and Present. Social Research: An International Quarterly. Editor: Charles Tilly. Volume 67, No. 3 (Fall 2000): 709-744. 